\section{Upper limb weakness and importance of immediate pain relief after cervical epidural steroid injections: more questions than answers?}

To the Editor

In their recent paper, McCormick et $a l^{1}$ report their observations using low-dose lidocaine on objective upper extremity strength and immediate pain relief following cervical interlaminar epidural steroid injections (CIESIs). In a randomized controlled trial (RCT), 120 patients with $\geq 4$ weeks of cervical radicular pain were randomized to have lidocaine-added CIESI (L-CIESI) or saline-added CIESI (S-CIESI) along with $80 \mathrm{mg}$ of triamcinolone acetonide. The primary outcome was upper extremity weakness, with $\geq 50 \%$ immediate pain relief reported as a secondary outcome measure. Adverse effects were collected 1 hour after the procedure. They observed no significant differences in the proportions of patients with post-procedural weakness and pain relief between groups. Although the authors should be commended for conducting a large, rigorous RCT, we feel there are important questions concerning generalizability that warrant attention.

By definition, chronic radicular pain refers to pain of at least 12 weeks' duration, with general recommendations being to avoid invasive interventions such as CIESI since a majority of patients will experience resolution as part of the natural course. $^{2}$ In this study, post-procedural weakness was noted in $42 \%$ of L-CIESI and $50 \%$ of S-CIESI patients. This finding should be concerning to pain specialists since unexplained weakness can be a sign of neurological compromise that necessitates a detailed neurological examination including emergent radiological imaging if indicated. Although the authors presumably discussed this possibility with patients beforehand, it is not clear whether they deemed weakness to be clinically meaningful or neurologically based. It is even more critical to understand the potential mechanisms since weakness was observed more frequently in the S-CIESI group, which precludes a lidocaine conduction block as the explanation. The authors considered post-procedure pain relief $\geq 50 \%$ as their success based on outcome measures for chronic pain trials, but this has no bearing on the long-term success of CIESI. Moreover, given the inclusion of patients with semi-acute pain and observations limited to the procedural period, can this be considered a chronic pain trial? Since CIESI carry significant risks, ${ }^{3}$ these considerations become critical both for research and clinical practice.

Although evidence on the effectiveness of CIESI in reducing cervical radicular pain is mixed, a majority of studies indicate possible benefits with epidural injections over non-epidural injections, ${ }^{4}$ and better results with CIESI when combined with physical therapy and medications. ${ }^{5}$ However, what constitutes the optimal therapeutic injectate is unclear, as local anesthetics alone have been shown to improve outcomes in patients with chronic pain, both in the short and long term. ${ }^{6}$ It is possible that the potential beneficial effect of local anesthetic may not be realized 20-30 min after the procedure. Four patients were excluded from the analysis and no intention-to-treat analysis was performed for pain relief. Yet despite this analysis, the risk difference was 9\% (32\%$19 \%$ ), which increased to $13 \%$ with just another patient success in the L-CIESI group, indicating fragility of the study results. ${ }^{1}$ Considering the risk-benefit ratio of steroids, it has been recommended that the lowest possible dose of steroids be used since there is no added benefit from using doses of depo-steroid above $40 \mathrm{mg} .{ }^{6}$ Given all the above considerations, the study conclusions should be applicable only to the study population and for immediate post-procedural outcomes, without any inferences on long-term results. We also implore the authors to consider longer follow-up periods to elicit patient-relevant clinical outcomes.

\section{Harsha Shanthhanna, ${ }^{1}$ Steven P Cohen $\odot{ }^{2}$} Samer Narouze ${ }^{3}$

'Department of Anesthesia, McMaster University, Hamilton, Ontario, Canada

${ }^{2}$ Department of Anesthesiology and Critical Care Medicine, Neurology and Physical Medicine \& Rehabilitation, Johns Hopkins School of Medicine, Baltimore, Maryland, USA

${ }^{3}$ Center for Pain Medicine, Western Reserve Hospital, Cuyahoga Falls, Ohio, USA

Correspondence to Dr Harsha Shanthhanna, Department of Anesthesia, McMaster University, Hamilton, Ontario L8S 4L8, Canada;

shanthh@mcmaster.ca

Twitter Harsha Shanthhanna @harshamd5 and Samer Narouze@NarouzeMD

Contributors All authors substantially contributed to writing and revising the letter. All had final approval.

Funding The authors have not declared a specific grant for this research from any funding agency in the public, commercial or not-for-profit sectors.

Competing interests SPC reports grants from MIRROR, US Department of Defense, Uniformed
Services University and the National Institutes of Health.

Patient consent for publication Not required.

Provenance and peer review Not commissioned; internally peer reviewed.

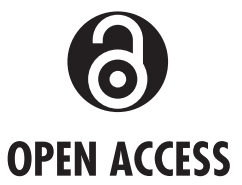

Open access This is an open access article distributed in accordance with the Creative Commons Attribution Non Commercial (CC BY-NC 4.0) license, which permits others to distribute, remix, adapt, build upon this work non-commercially, and license their derivative works on different terms, provided the original work is properly cited, an indication of whether changes were made, and the use is non-commercial. See: http:// creativecommons.org/licenses/by-nc/4.0/.

(C) American Society of Regional Anesthesia \& Pain Medicine 2021. Re-use permitted under CC BY-NC. No commercial re-use. Published by BMJ.

\section{Check for updates}

To cite Shanthhanna H, Cohen SP, Narouze S. Reg Anesth Pain Med Epub ahead of print: [please include Day Month Year]. doi:10.1136/rapm-2020102386

Received 10 December 2020

Accepted 16 December 2020

\section{S Linked}

- http://dx.doi.org/10.1136/rapm-2021-102499

Reg Anesth Pain Med 2021:0:1.

doi:10.1136/rapm-2020-102386

ORCID iD

Steven P Cohen http://orcid.org/0000-0001-5928-2127

\section{REFERENCES}

1 McCormick ZL, Burnham T, Cunningham S, et al. Effect of low-dose lidocaine on objective upper extremity strength and immediate pain relief following cervical interlaminar epidural injections: a double-blinded randomized controlled trial. Reg Anesth Pain Med 2020:45:767-73.

2 Bicket MC, Hurley RW, Moon JY, et al. The development and validation of a quality assessment and rating of technique for injections of the spine (Aquarius). Reg Anesth Pain Med 2016:41:80-5.

3 Eworuke E, Crisafi L, Liao J, et al. Risk of serious spinal adverse events associated with epidural corticosteroid injections in the Medicare population. Reg Anesth Pain Med 2020:4:rapm-2020-101778.

4 Bicket MC, Gupta A, Brown CH, et al. Epidural injections for spinal pain: a systematic review and meta-analysis evaluating the "control" injections in randomized controlled trials. Anesthesiology 2013;119:907-31.

5 Cohen SP, Hayek S, Semenov Y, et al. Epidural steroid injections, conservative treatment, or combination treatment for cervical radicular pain: a multicenter, randomized, comparative-effectiveness study Anesthesiology 2014;121:1045-55.

6 Shanthanna H, Busse J, Wang L, et al. Addition of corticosteroids to local anaesthetics for chronic noncancer pain injections: a systematic review and metaanalysis of randomised controlled trials. $\mathrm{Br} J$ Anaesth 2020;125:779-801. 